\title{
From offender to victim-oriented monitoring: a comparative analysis of the emergence of electronic monitoring systems in Argentina and England and Wales
}

De um monitoramento focado no ofensor a um focado na vítima: uma análise comparativa do surgimento de sistemas de monitoramento eletrônico na Argentina e na Inglaterra e País de Gales

Craig Paterson

\section{Abstract}

The increasingly psychological terrain of crime and disorder management has had a transformative impact upon the use of electronic monitoring technologies. Surveillance technologies such as electronic monitoring - EM, biometrics, and video surveillance have flourished in commercial environments that market the benefits of asocial technologies in managing disorderly behavior and which, despite often chimerical crime prevention promises, appeal to the ontologically insecure social imagination. The growth of EM in criminal justice has subsequently taken place despite, at best, equivocal evidence that it protects the public and reduces recidivism. Innovative developments in Portugal, Argentina and the United States have re-imagined EM technologies as more personalized devices that can support victims rather than control offenders. These developments represent a re-conceptualization of the use of the technology beyond the neoliberal prism of rational choice theories and offender-oriented thinking that influenced first generation thinking about EM. This paper identifies the socio-political influences that helped conceptualize first generation thinking about EM as, firstly, a community sentence and latterly, as a technique of urban security. The paper reviews attempts to theorize the role and function of EM surveillance technologies within and beyond criminal justice and explores the contribution of victimological perspectives to the use of EM 2.0.

Keywords: Electronic monitoring. Criminal justice. Victim-orientation. Policy transfer.

\section{Resumo}

O crescente terreno psicológico da gestão do crime e desordem tem tido um impacto transformador sobre a utilização das tecnologias de monitorização eletrônica. As tecnologias de vigilância, tais como monitoração eletrônica (ME), biométrica e vigilância por câmeras floresceram em ambientes comerciais que vendem os benefícios das tecnologias associais na gestão de comportamentos desordenados e que, apesar de promessas de prevenção de crimes, muitas vezes quiméricas, apelam para a imaginação social ontologicamente insegura. A ME se expandiu na justiça criminal apesar de, na melhor das hipóteses, haver provas equívocas de que protege o público e reduz a reincidência. Desenvolvimentos inovadores em Portugal, Argentina e nos Estados Unidos reimaginaram as tecnologias de ME como dispositivos mais personalizados que podem apoiar as vítimas, em

CP is PhD, Principal Lecturer in Criminology, e-mail: c.paterson@shu.ac.uk 
vez de controlar os agressores. Estes desenvolvimentos representam uma reconceitualização da utilização da tecnologia além do prisma neoliberal das teorias de escolha racional e pensamento orientado para o agressor que influenciaram os primeiros pensamentos sobre a ME. Este artigo identifica as influências sociopolíticas que ajudaram a conceitualizar os primeiros pensamentos sobre a ME, como, em primeiro lugar, uma sentença comunitária e, mais tarde, como uma técnica de segurança urbana. $O$ artigo critica tentativas de teorizar o papel e função das tecnologias de vigilância ME no âmbito e além da justiça criminal, explorando a contribuição das perspectivas de vitimologia para a utilização da ME 2.0.

Palavras-chave: Monitoramento eletrônico. Justiça criminal. Apoio a vítimas. Transferência de políticas públicas.

\section{Introduction}

The increasingly psychological terrain of crime and disorder management strategies has had a transformative impact upon the use of electronic monitoring (EM) technologies. Surveillance technologies such as EM, biometrics, and CCTV have flourished in commercial environments that market the benefits of asocial technologies in managing disorderly behavior and which, despite often chimerical crime prevention promises, appeal to the ontologically insecure social imagination. The growth and consolidation of EM across criminal justice systems has subsequently taken place despite, at best, equivocal evidence that it protects the public and reduces recidivism. Instead, crime control surveillance technologies focus upon public and private spaces in deprived socio-economic areas via attempts to reconfigure social space and manage risky populations. Therefore, while the emergence of EM technologies and programs may initially appear to represent innovations in criminal justice they are better understood as component parts of an intensification of urban surveillance and electronic population governance.

The first generation of EM programs attempted to restrict the movement of offenders to their own private space via curfew orders yet innovative developments in Argentina, the United States and Portugal have subsequently re-imagined EM technologies as more personalized devices that can support repeat victims and enhance public safety. These second generation developments with EM represent a re-conceptualization of the role and function of the technology beyond the neoliberal prism of rational choice-based, offender-oriented thinking that influenced first generation developments. In order to make sense of the re-conceptualization of EM this paper reviews initial attempts to theorize the role and function of EM surveillance technologies within criminal justice and outlines the socio-political influences that helped conceptualize first generation thinking about EM as, firstly, a community sentence and, latterly, as a technique of urban security in England and Wales. The paper subsequently explores the contribution of victim-oriented perspectives to the use of EM, using a case study from Argentina, and concludes with some commentary on the untapped potential of victim-oriented electronic monitoring (VOEM) within criminal justice and citizen security.

\section{Exploring the role and function of electronic monitoring}

First generation EM technologies emerged out of a post-Cold War context where advances in military and technological approaches to population control in foreign jurisdictions were re-redirected towards the national citizenry. Early EM programs attempted to structure the movement of offenders across time and space via curfew restrictions that kept individuals within their homes at specified points of the day when they were perceived to present a risk to the local community. Early attempts to theorize the role and function of EM highlighted the potential for it to be restrictive (Ball et al., 1988), rehabilitative (Whitfield, 1997), punitive (Nellis, 1991; Renzema, 1992) and managerialist (Mair, 2005). The many and varied interpretations of the purpose of EM reflected what was an experimental phase for the technology and the absence of a clear evidence-base articulating best practice.

The failure of first generation EM programs to deliver clear outcomes aligned to coherently designed 
aims encouraged a re-conceptualization of EM that recognized that its role and function were not situated within traditional penal thinking about the aims and purpose of sentencing. Attempts to theorize EM during the 1980s and 1990s reflected societal concerns about excessive surveillance and over-emphasized structure ahead of agency (Paterson, 2007) whilst neglecting the theoretical potential in conceptualizing EM as a locus of surveillance that seeks to locate and regulate the movement and behavior of an individual. Nellis (2009, p. 59) sought to re-situate thinking about EM within the context of developments in e-governance in neoliberal political economies that emphasized virtual at-distance monitoring of risky populations:

Contemporary computerized control technologies can structure and modulate a person's mobility in space and time by micro-managing external environmental pressures -- openings here, barriers there, inclusion now, exclusion later -- rather than seeking to change their personality (alter their way of thinking). Changing thought -- the traditional intention of discipline -- becomes less vital if the state can regulate sufficiently well in other ways -- co-opting and customizing the emergent telecommunications infrastructure to enable remote location monitoring.

This conceptualization of EM as a Deleuze (1992) mode of control further emphasizes agency and the potential for offenders to engage with a system of rules and regulations. Thus, EM becomes understood as a socio-technical practice that situates the locatability of an offender within modes of governance that emerge under different socio-political and cultural conditions - a technique of urban security in some places; a community sentence in others. Understanding EM as socio-technical practice resonates with other areas of surveillance theory which emphasize the importance of social actors in the design and implementation of surveillance-based programs (McCahill \& Finn, 2013).

Any long-term rehabilitative or disciplinary impact that can be derived from EM-based programs represents 'added value' to crime control agencies but is incidental to the central role and function of the technology with its emphasis on surveillance-based regulatory control. It is therefore possible to tie developments in first generation EM to demands for new technological and commercially cost effective solutions to social problems rather than to innovations in criminal justice. Interpreting developments in EM as new modes of e-governance and regulatory control draws explicit links with policing theories and the role of EM within a complex of complementary, targeted strategies of governance of populations that on a range of indicators have been deemed to represent high levels of collective risk (Paterson, 2008). Thus, the broader purpose of EM, understood with the context of evolving strategies of e-governance, is to generate an "intensification in the militaristic capabilities that state servants have at their disposal and the range of practices initiated towards the policing of social boundaries" (Coleman \& Sim, 2000, p. 634).

It is an old theme in policing research that much front line work does not involve the direct enforcement of law and legal authority provides a background of legitimacy for governing problematic people and situations via the flexible use of individual discretion (Bittner, 1970). Hence, sovereign legal authority blurs into the authority to make normative judgments about individual or collective behavior and the decision to exercise regulatory controls. Similarly, the role and function of first generation EM curfew orders can be understood as a mode of electronically governing potentially problematic populations and situations across public and domestic space via the use of at-a-distance technology that generates a sense of sovereign intervention for the individuals under surveillance. Following on from Bittner, EM can be understood as an appeal to the offender's imagination and an attempt to distribute psychologically imagined coercive force that both constructs and deconstructs the social boundaries that are policed. While attempts to conceptualize the meaning of policing and surveillance under the auspices of crime control are often reduced to discussions about the role and function of agencies and officers it is this broader psychologically imagined response to observation from potential offenders and wider society that influences policy design and determines successful policy implementation.

The influence of the social and psychological imagination upon responses to crime and security has been increasingly recognized within the academic literature (Cheliotis, 2013), particularly developments in e-governance which simultaneously enhance regulation and appeal to wider public insecurities about an absence of social controls. The potential for surveillance technologies to address public anxieties about crime via the construction of virtual and 
imagined boundaries of inclusion/exclusion is well documented (Lyon, 2007; Young, 2007). The failure of first generation EM to capture public support resulted largely from a perception that the surveillance was insufficiently extensive and intrusive. The emergence of web 2.0, social media and mobile technologies made first generation EM appear inflexible, unimaginative and immobile. Most importantly, the experience of being subject to surveillance in the new millennium became increasingly commonplace and western interpretations of the role of surveillance in society slowly mutated from an emphasis on Orwellian and Panoptic metaphors to the integration of a more emancipatory and politically libertarian discourse (McGrath, 2004). Interpretations of first generation $\mathrm{EM}$ as restrictive and punitive became increasingly difficult to support and a transition to second generation EM that utilized GPS and GSM technology emerged.

The emphasis on mobile and real-time monitoring provided by second generation EM has the potential to act as a source of reassurance and support for those under threat of repeat victimization. Erez \& Ibarra's (2007) evaluation of bilateral (offender and victim) EM systems in the United States identified an impact on the way that victims' interpret their own safety once a program has been instigated that validates their safety concerns. This includes the positive influence of criminal justice personnel engaging directly with victims and recognizing their right to protection. In this context, EM provides a structure within which specially trained individuals build positive relationships that support recovery and avoid the damaging impact of victims' perceiving that their problem has been trivialized by agencies or individuals. This increasingly victim-oriented approach has the potential to re-configure how individuals identify with and function in social spaces as their confidence and resilience is re-built in the absence of physical threat. Police officers perform a key role in recognizing the continued threat to an individual, consistently promoting the message that domestic violence is unacceptable, and reinforcing a victims' sense of their right to occupy space (Erez \& Ibarra, 2007, p. 103; Taylor, 2012).

The historical absence of emphasis upon citizen security and repeat victimization had left a range of vulnerable populations with a security deficit yet policy trajectories across criminal justice systems, and specifically within electronic monitoring programs, increasingly emphasize victims' interests and the emotional and psychological benefits of victim-oriented policy (Ibarra \& Erez, 2005; Rosell, 2011; Ferreira et al., 2012). The lived experience of those subject to surveillance has been subjected to enhanced scrutiny although this experience is often misunderstood within the policy arena. VOEM actively challenges the offender-oriented assumptions and priorities of state, private and third sector officials and their tendency to focus upon victims' administrative needs - such as rights, voice and satisfaction - to the detriment of experiential and actualized notions of victim safety and mechanisms for building resilience (Walklate, 2011; Duggan \& Heap, 2014). In the Buenos Aires case study, traditional criminal justice agencies remain stakeholders but the emphasis placed upon the individual as the active decision-maker (Christie, 2008) takes the concept of bi-lateral EM further and delineates VOEM from previously offender-oriented policy.

The emphasis placed on individual well-being, positive social identify and inter-personal relationships avoids disempowerment and emphasizes the role of the surveilled individual as an active social agent. Despite the theoretical promise of VOEM programs there remain a number of challenges to policy development and implementation - most notably, the tendency of governance structures to co-opt innovation for its own purposes. In order to draw lessons from these challenges the next section provides a review of the socio-political dynamics evident during the emergence of first generation EM in the England and Wales and their influence over policy development.

\section{The emergence of first generation electronic monitoring: a case study from England and Wales}

The evolution and global diffusion of EM is indicative of increased demand for security and surveillance technologies across developed global societies. This demand for experimentation in new control technologies is particularly evident in England and Wales which has acted as a site of experimentation for technologies such as EM, CCTV and Automatic Number Plate Recognition. In England and Wales EM-based curfew orders, which most commonly restrict movement for twelve hours overnight, have been used for individuals sentenced by courts or released early from prison although 
there have been a range of smaller experiments with pre-trial measures, integrated programs for high risk offenders and protective measures such as exclusion orders. Despite this, the preponderance of offender-focused thinking within crime control policy elites has the potential to marginalize the use of surveillance technologies in the enhancement of citizen security, particularly where there is a likelihood of repeat victimization and an escalation of violence. The continued governmental emphasis upon the regulation of offenders, to the detriment of individual and collective protection, is a direct consequence of the dominance of deterrence-based models of thinking coupled with the punitive and disciplinary logic that pervades political approaches to policing and crime control in England and Wales and other jurisdictions (Paterson, 2012).

More precisely, a notable characteristic in the design of surveillance responses to social risks is the tension between the over-arching socio-cultural context of capitalist political economy and local demands for democratic governance and security. A litany of empirical examples point to the limited effectiveness of surveillance technologies in managing problems of crime and disorder (Coleman \& Sim, 2000; Mair, 2005; Gill \& Spriggs, 2005; McCahill \& Finn, 2013) yet these technologies continue to receive sustained investment and point to the predominance of capitalist political economy in shaping the contemporary architecture of surveillance-based crime control and first generation EM. This policy trajectory can marginalize demands for security that emerge out of local structures and lead to policy developments that reflect the interests of political, policy and commercial sites of power.

The complex interplay between structural issues, such as socio-economic context, and the agency of social actors in the formulation of EM policy directs scholarly interest towards the role of policy elites within each nation state; thus, what emerges in the rest of this paper is a comparative study of mentalities of control and their influence over policy development and implementation. The study of policy elites recognizes the importance of professional habitus plus the cognitive repertoire of dispositions, assumptions and values of personnel involved in policy development and implementation (Stenson, 2005). While a global perspective on first generation EM focuses on neoliberal political economy and the expanding role of commercial organizations in western criminal justice systems, a focus upon the contested struggle for sovereignty at the local level provides a more complex picture of rival agencies involved in shifting alliances with the state and the modes of governance this produces. This political struggle becomes visible via analysis of a complex of actors from political, policy and commercial sites in constructing first generation EM policy.

Similar patterns of growth in first generation EM were also evident in the United States and Canada which experienced complementary neoliberal economic reforms alongside tough, law and order policies and rising incarceration rates. The law and order politics of the 1980s, inspired by right-wing criminologists such as James Q Wilson and Charles Murray, had revived concern with the Victorian residuum, or underclass, and influenced policy developments across English-speaking neoliberal economies. Right wing think tanks such as the Adam Smith Institute marketed criminal justice privatization to England and Wales as a solution to the problem of the urban poor. This political and economic dynamic helps explain the arrival of EM in England and Wales in 1989 alongside a dearth of supportive research evidence but key cheerleaders from the worlds of commerce and politics (Mair, 2005; Paterson, 2008). The number of EM-based curfew orders (and a range of associated regulatory programs) grew in truncated spurts followed by accompanied bouts of stagnation for two decades as political will waxed and waned against a backcloth of scattergun policy experimentation. By 2013 , this fragmented policy evolution had led to approximately 25,000 people being subject to some form of first generation EM on a daily basis despite continued public and professional uncertainty about what EM programs intended to achieve.

The continuation of this policy trajectory remains evident in a more recent Policy Exchange paper entitled 'Future of Corrections' (2012) which lauds a vision of EM in the UK where 140,000 offenders are monitored at any one time by GPS technology. Policy Exchange, an influential Conservative think tank which supports the privatization of criminal justice and has established links with the EM industry in the United States, sought to capitalize on the Conservative party's mistrust of the Probation Service and existing commercial providers to propose a radical way forward for EM (Paterson, 2014). The ambition to drive growth from the 2014 position of 25,000 monitored offenders was unsurprising to 
those who have observed the development of EM yet the scale of the 'Future of Corrections' vision seeks to fundamentally re-shape the landscape of community supervision in the UK. The central argument of 'Future of Corrections' is that the ineffective and costly use of EM occurred due to market failure and the consolidation of a commercial duopoly that stifled innovation and legitimated poor practice. The evidence-base for this assertion draws upon the United States model of local governance structures and EM service delivery which produced more positive findings about the effectiveness of GPS EM in reducing recidivism (Padgett et al., 2006). The sub-text of 'Future of Corrections' implies that the failure of first generation EM was caused by insufficiently intrusive and intensive surveillance and control of offenders. First generation EM had proved both insufficiently punitive for law and order lobbyists and inadequately effective for those who sought an unequivocal evidence-base. Thus, the historical trajectory of EM policy in England and Wales continues to be to do more things to offenders (introduce new programs or technologies), and to do this more extensively and punitively (for example, to increase curfew length or associated conditions).

EM was conceived as a deterrence-based mode of regulatory control, like first generation CCTV, yet experimentation with a range of programs and technologies has produced mixed findings concerning recidivism rates (Renzema, 1992; Padgett et al., 2006). The reasons for this are clear: Offenders rarely want to comply with the restrictions placed upon them by technology and subsequently develop adaptive strategies that displace, resist and reformulate offending behavior in new forms and arenas (Paterson, 2007). Thus, while electronic monitoring generates a restrictive framework for offender movement across time and space, these restrictions have little enduring impact on patterns of behavior. These limitations raise questions about the value of regulatory modes of governance, such as EM. Yet, the chimera of security and crime prevention provided by pre-emptive surveillance technologies is supported by ideologically constructed perceptions about the control of disorderly groups that predominate within political discourse, popular myth and carefully constructed public relations.

In consequence, first generation EM should be understood as a mechanism for enhancing the punitive aspects of community supervision and meeting public demand for enhanced control of offenders within a financially constrained environment. EM subsequently becomes understood as a component of the increasingly psychological terrain of crime and disorder perception management via electronic modes of population management that appeal to the ontologically insecure social imagination (Young, 2007). The neo-classical, deterrence-based focus of EM policy development is further influenced by its implementation via the private sector and the drive to expand its use that prevails via influential think tanks and populist politicians (Paterson, 2012). It is within these policy elites that the struggle to make sense of evolving concepts such as VOEM runs into the conceptual dominance of rational choice-based offender-oriented thinking. The dominance of rational choice and routine activity perspectives on population management amongst policy elites coupled with the top-down administration of criminal justice creates a rupture between theoretical thinking, conceptual design and policy implementation. Yet, EM program development is by no means uniform with commercial organizations promoting neoliberal technologies of control whose aims and purpose metamorphose within each nation state's social, political and economic context and emphasize the potential for innovation. The following case study from Argentina highlights how the influence of a different context and a distinct set of policy actors led to the establishment of an EM program which placed repeat victims at the heart of policy development.

\section{VOEM: re-imagining electronic monitoring in Argentina}

The global spread of EM is evident across Latin America where Brazil, Argentina, Uruguay, Chile, Colombia and Mexico have established EM programs (UNODC, 2013). In Argentina, initial policy development focused on the emulation of existing EM programs via a process of policy transfer between policy elites from the UK and Argentina (Snelgrove, 2010). Conversely, the development of a victim-oriented EM program emerged out of more localized concerns about citizen security - in particular, startling rises in violence against women (Solano, 2012; Sibilla, 2012). In this instance, policy development was driven from below via community action groups and public concern about the threat of violence that encouraged Buenos Aires 
government officials and a newly established City police to experiment with existing technologies and provide an innovative crime control response that involves self-selecting at-risk users and the role of late-modern citizens as co-producers of urban policy: EM 2.0, if you will.

While there had been small experiments with first generation offender monitoring in Argentina (Di Tella \& Schargrodsky, 2013), the City Government of Buenos Aires and the Buenos Aires Police invested in a victim monitoring program that aimed to enhance individual safety in a country experiencing heightened public concern about violent crime. Within this context the surveillance technology aimed to deliver resource savings for the police alongside flexible at-a-distance monitoring with an emphasis upon potential repeat victimization and citizen security. The Buenos Aires system places the police in a position where their primary role is to protect the vulnerable person via pre-emptive alerts to potential offences and situates the active individual in an empowered position to contribute to their own safety. In a police repeat victimization suite staff monitor panic button calls from individuals who are considered to be at high risk of domestic or street violence. The panic button system is connected directly to a specialist response suite within the police communications center which immediately identifies the location of the person at-risk and the most relevant response unit. A support communications worker also provides guidance. The holistic nature of this victim-oriented, social crime prevention program utilizes the technology as just one strand within a package of social and psychological support that emphasizes victim re-entry into society. The system represents an acknowledgement of the limits of the city's capacity to protect vulnerable victims of violence alongside a desire to facilitate a smarter use of scarce police resources.

Latin American developments in policing and surveillance have to be understood within the context of historically troubled police-community relations that, in Argentina, remain characterized by low levels of trust and enduring questions about resources, effectiveness and corruption (Eaton, 2008). The broader socio-political context of concerns about citizen security coupled with local complaints about ineffectiveness and mistrust led to the establishment of the Buenos Aires City Police in 2010 and the evolution of a both localized (administratively at the city level) and centralized (co-ordinated by the City police) surveillance structure. Local concern about a security deficit led to simultaneous calls for a populist 'Mano Dura' (tough hand) alongside a more pragmatic responsibilisation strategy due to the limited capacity of state resources (Garland, 2002). This acknowledgement of state security failure amongst local policy elites within an environment where public concern about police corruption, civil liberties and privacy is salient created the space for criminal justice innovation. While urban renewal strategies in advanced economies engage with principles such as innovation, social inclusion, community orientation and co-production the role of various policy elites influences how these macro sociological factors manifest themselves in policy and practice. Thus, there is evidence of congruence with UK developments in new modes of e-governance yet the formulation of policy from the bottom-up has generated a greater focus on the safety and security demands of individuals and communities.

While there remain important comparative distinctions between the new centralized digital surveillance infrastructure that is run from the Buenos Aires City Police Headquarters and the privatized analogue monitoring of curfew orders in England and Wales it is possible to identify a process through which the use of technology was imagined, policy designed, and a mode of e-governance developed. It is this contested arena of criminal justice governance and policy implementation that will be the focus of the final section of this paper. The evolution of the panic button program objectives within women's groups in Buenos Aires emphasized the importance of local social capital as a mechanism to conceptualize and build programs that continue to be owned by local state actors alongside statutory institutions. While the concept of the local state is not without its problems, bottom-up policy development navigates the field of policy elites and allows local communities to impose their imagined spatialities of crime and disorder upon policy development via alliances with more powerful institutions. There remains a need to nurture, guide and resource new agents of social development to stop the local state becoming a site of vested interests but comparative analysis of the Buenos Aires case study demonstrates how policy generated by the local state can work without co-option by the offender-orientation evident in England and Wales. 
The victim-oriented approach harnesses the same ontological insecurity that drives growth in neoliberal crime control but mobilizes the public protection qualities of surveillance technologies at the individual level. An appreciation of relational space (Massey, 2005) rather than physical space helps explain how the imagined potential of surveillance can aid victim re-entry into society and a slow build-up of confidence to re-use and own public space. The academic literature on ontological insecurity (Garland, 2002; Young, 2007), which has dwelt most commonly on public fear, provides support for the imagined potential of surveillance although there are substantive critiques of such a system, most notably from Marxist and feminist scholars, who point to an intrinsic incompatibility between victim support and law enforcement. Having introduced two short case studies the final substantive section analyzes the theoretical potential and limitations of VOEM as well as the challenge of policy implementation.

\section{From offender to victim-oriented monitoring?}

A comparative study of the emergence of EM systems in the UK and Argentina generates meaningful findings due to similarities in experiences of the development of new surveillance systems and cultural differences generated by distinctions in political structures, socio-economic status, state responses to crime and disorder, plus experiences of crime and penal globalization. Penal globalization refers to the sharing of ideas and practices about criminal justice across international jurisdictions with the objective of drawing lessons from mutual yet differentiated experience of crime problems. In this instance, it is patterns and trajectories of policy development that influence the emergence of new modes of surveillance-based crime control that provides the nexus of study between the two states. Global Cities are increasingly characterized by patterns of social interaction within urban environments that are captured via remote sensing frameworks and the proliferation of wireless technologies and ubiquitous computing. Extracting EM from crime control discourse releases the potential to utilize everyday technology within innovative policy and programs. A re-conceptualization of EM as a user-friendly technology (potentially built into a phone or other mobile device) has the potential to delineate VOEM from the reductive and punitive offender-oriented discourse of monitoring, tagging and restriction. By framing the potential utility of VOEM within a recognition of the protective factors generated by surveillance-based attempts to distribute psychologically imagined coercive force it becomes possible to envisage new ways of imagining and developing EM that remain responsive to local demands for policing and security.

The priority of the criminal justice process is to achieve justice rather than to protect the citizen. This process has the potential to generate a security deficit and marginalization of vulnerable people. The early part of this paper emphasized the importance of understanding EM as a socio-technical practice to reflect the importance of social actors in the design and implementation of surveillance-based programs. Utilizing interactive policy-making where the public are actively engaged as stakeholders far ahead of delivery or implementation, enables a conceptualization of programs that appreciate the lived experience of victims, addresses security deficits and avoids the prospect of process-oriented co-option. There is already evidence of a victim-orientation within aspects of EM policy that includes exclusion orders and notifications for victims when an offender breaches an order. GPS-enabled exclusion orders have demonstrated a significant impact upon the behavior of perpetrators (Erez et al., 2012) although they remain conceptually distinct from the Buenos Aires case study which places greater emphasis on the agency of the victimized person ahead of the offender.

Surveillance programs that emerge out of demands from communities where the associated problems lie can demonstrate a better appreciation of relational space with its focus on affiliation, linkage and flow (Amin, 2004). This may help explain how the imagined potential of surveillance can aid victim re-entry into society and runs contrary to the policy elite focus on e-governance and offender management within imagined physical spaces. The untapped potential of VOEM programs lies within the ambiguities that exist in individual and collective interpretations of surveillance capacity. This paper has outlined how the evidence-base from offender-oriented programs demonstrates that, with an incomplete comprehension of the technology, individuals amplify the surveillance potential of EM. Thus, security and surveillance strategies do not necessarily respond to rational thinking and 
are driven by a mixture of technological fetishism and instinctive emotional responses. CCTV provides an excellent example of a technology whose potential is based upon a mythologized crime prevention status that is popular with the public but unsupported by evidence (Webster, 2009). Harnessing this mythology within developments in e-governance and policing presents new opportunities for policy-makers.

The contested nature of the police role has been increasingly recognized by police organizations across the globe and strategic developments in areas such as public reassurance and officer civility demonstrate a continued shift of the role and function of policing agencies beyond traditional crime-fighting functions and towards preventive protection. These policy trajectories remain uneven both within and across jurisdictions but highlight the potential of VOEM programs where they are shown to invoke feelings of safety. The governing instincts and dispositions of contemporary political actors tend to direct the surveillance gaze towards expansionary e-governance strategies and offender management which marginalizes victims and innovative approaches to citizen security. The resultant security deficits experienced by vulnerable populations leads to continued dissatisfaction with criminal justice agencies but this process can be challenged when local state actors retain an active role.

Cavadino \& Dignan (2006) argue that the political economy of neoliberal societies leads to exclusionary social and political policies alongside ingrained exclusionary cultural attitudes towards deviance, disorder and their social management. Thus, policing, surveillance and social control in the neoliberal era is most commonly characterized by greater regulatory controls, social exclusion, segregation and the exacerbation of relative deprivation (Nolan, 2008). Yet, this paper has highlighted the limitations of deterministic structural theories that marginalize the role of social actors. The Buenos Aires case study emphasizes the role of local actors and newly established institutions in re-imagining the role and function of EM. Similarly, in England and Wales, recent legislative and policy changes have attempted to strengthen local governance structures within a context of fiscal retrenchment and this has led to more imaginative use of EM via a range of pilot programs. The limited explanatory value of governance perspectives is a legacy of Foucault's enduring message that 'nothing works', that power stratifies and sovereignty reigns, and that agency is subordinate to structure (Foucault, 1980). While this theoretical framework may be applicable to strong sovereign states it does not necessarily apply to those in a process of neoliberal rollback or those under strict financial restraints where building local sovereignty from below represents an essential component of the policy process. It follows that the dynamics of political economy have the potential to influence institutional ideology and the purpose of surveillance systems but that these macro level factors must be understood within the context of local politics and organizational cultures.

Given this context it is unsurprising that victim-oriented programs have been criticized for the extension of coercive control that has been exercised under the auspice of victim focus and protection. For example, there is evidence that, despite the high risk status of repeat victims, many police officers continue not to regard domestic violence cases as a core police function (Loftus, 2010). Added to this, Dutch and American studies found that victims often do not use panic buttons as they associate the technology with a potential criminal justice outcome for the perpetrator (Römkens, 2006; Erez et al., 2012). Therefore, even when there is an emphasis on victim perspectives, victim-oriented strategies can be co-opted by more traditionally powerful punitive voices and innovative policy realigned with the neo-classical offender-oriented perspectives that prevail throughout the centers of governmental power. This is a longstanding factor in discussions about policing and surveillance which have a tendency to focus on repressive control functions rather than a potential to care and support (Moore, 2011).

There is also potential for victim-oriented programs to be co-opted by dominant ideologies of regulation and control that stratify opportunities along lines of class, gender and ethnicity. Revanchist state policies towards urban poverty and the urban poor are often imagined within the context of middle class sensibilities. This raises questions about the extent to which police-led victim-oriented programs are anything more than symbolic social and cultural messages to the voting classes and whether victim-oriented policies can translate beyond discourse into practice rather than being re-conceptualized within a crime-fighting framework (HMIC, 2014; Sklansky, 2011).

A further problem with state responses to patriarchal violence lies within their tendency to further entrench 
structures of oppression. Technologies such as EM structure activities within the home and have repeatedly been shown to make demands on other, most commonly female, family members (Paterson, 2007). Comprehension of the threat of violence to women has been historically low within the arena of policy design and policy implementation leading to the potential for new surveillance technologies to intensify the threat of stalking and subsequent violence. The ability of surveillance to dismantle and disaggregate personal identity and then to subsequently reconstruct a virtual identity can lead to the re-enforcement of modes of domestic surveillance. Consequently, attentiveness to structures of oppression needs to be embedded in analysis of responses to surveillance from repeat victims of violence to understand the experience of epistemological and ontological violence. The Buenos Aires case study demonstrates the importance of engaging local actors in the process of policy development to ensure victims are placed at the center of the process and to avoid unintentional policy outcomes.

\section{Conclusion}

EM technologies initially emerged out of an analogue surveillance environment with limited potential to rationalize space. The shift to digital surveillance creates the real possibility to order dangerous spaces for at-risk groups and individuals as part of evolving strategies of electronic population governance. First generation EM was driven by a desire to restore order and control over disorderly public spaces and it was expected that this enhanced regulatory control would appeal to public concern with rule compliance. Unfortunately, first generation virtual interventions have been much maligned. Second generation EM attempts to control space on behalf of vulnerable citizens represent a potentially more fruitful path through the formalization of protective strategies that build a sense of security via a combination of imagined and actualized security.

The two case studies used in this paper demonstrate that analysis of EM should recognize the complex interplay of structure and agency and be cognizant of their influence during policy design and development. The surveillance capacity generated by new modes of crime control, and their promises of technical solutions to crime problems, often diverts attention away from the central role of human agency, local politics, institutional ideology and culture which influence how surveillance technologies emerge in policy and practice. Re-aligning the balance between structure and agency in theoretical analysis of VOEM acknowledges the potential to produce and reproduce various forms of social inequality via policy development that insufficiently engages with the potential of local actors. This perspective also provides a potential way forward for the integrated use of surveillance technology in the enhancement of individual and collective citizen security.

\section{References}

Amin, A. (2004). Regions unbound: towards a new politics of place. Geografiska Annaler, 86(1), 33-44. http://dx.doi. org/10.1111/j.0435-3684.2004.00152.x

Ball, R., Huff, R., \& Lilly, R. (1988). House arrest and correctional policy: doing time at home. Thousand Oaks: Sage.

Bittner, E. (1970). The functions of the police in modern society. Maryland: National Institute of Mental Health.

Cavadino, M., \& Dignan, J. (2006). Penal policy and political economy. Criminology \& Criminal Justice, 6(4), 435-456. http://dx.doi.org/10.1177/1748895806068581

Cheliotis, L. (2013). Neoliberal capitalism and middleclass punitiveness: bringing Erich Fromm's "materialistic psychoanalyis" to penology. Punishment and Society, 15(3), 247-273. http://dx.doi.org/10.1177/1462474513483692

Christie, N. (2008). Fertile ground for victim-movements. In Third Nordic Conference on Victimology and Victim Support. Helsinki.

Coleman, R., \& Sim, J. (2000). 'You'll never walk alone': CCTV surveillance, order and neo-liberal rule in Liverpool city centre. The British Journal of Sociology, 51(4), 623639. http://dx.doi.org/10.1080/00071310020015299. PMid:11140887

Deleuze, G. (1992). Postscript on the societies of control. October, 59, 3-7.

Di Tella, R., \& Schargrodsky, E. (2013). Criminal recidivism after prison and electronic monitoring. Journal of Political Economy, 121(1), 28-73. http://dx.doi.org/10.1086/669786

Duggan, M., \& Heap, V. (2014). Administrating victimization. Hampshire: Palgrave MacMillan. 
Eaton, K. (2008). Paradoxes of police reform: federalism, parties, and civil society in Argentina's public security crisis. Latin American Research Review, 43(3), 5-32. http:// dx.doi.org/10.1353/lar.0.0053

Erez, E., \& Ibarra, P. (2007). Making your home a shelter: electronic monitoring and victim re-entry in domestic violence cases. The British Journal of Criminology, 47(1), 100-120. http://dx.doi.org/10.1093/bjc/azl026

Erez, E., Ibarra, P., Bales, W., \& Gur, O. (2012). GPS monitoring technologies and domestic violence: an evaluation study. United States Department of Justice. Retrieved in 30 January 2015, from https://www.ncjrs.gov/pdffiles1/nij/ grants/238910.pdf

Ferreira, N., Caiado, N., \& Pinto, S. (2012). L'experience Portugaise de surveillance electroniqueet violence domestique. In Confederation of European Probation Conference. Sweden.

Foucault, M. (1980). Power/knowledge: selected interviews and other writings, 1972-1977. Brighton: Harvester.

Garland, D. (2002). The culture of control. Chicago: University of Chicago Press.

Gill, M., \& Spriggs, A. (2005). Assessing the impact of CCTV. London: Home Office.

Her Majesty's Inspectorate of Constabulary - HMIC. (2014). Everyone's business: improving the police response to domestic abuse. London: HMIC.

Ibarra, P. R., \& Erez, E. (2005). Victim-centric diversion? The electronic monitoring of domestic violence cases. Behavioral Sciences \& the Law, 23(2), 259-276. http:// dx.doi.org/10.1002/bsl.639. PMid:15818606

Loftus, B. (2010). Police occupational culture: classic themes, altered times. Policing and Society, 20(1), 1-20. http://dx.doi.org/10.1080/10439460903281547

Lyon, D. (2007). Surveillance studies: an overview. Cambridge: Polity.

Mair, G. (2005). Electronic monitoring in England and Wales: evidence-based or not? Criminology \& Criminal Justice, 5(3), 257-277. http://dx.doi.org/10.1177/1466802505055836

Massey, D. (2005). For space. London: Sage.

McCahill, M., \& Finn, R. (2013). The surveillance of prolific offenders: beyond docile bodies. Punishment and Society, 15(1), 23-42. http://dx.doi.org/10.1177/1462474512466198

McGrath, J. (2004). Loving big brother: performance, privacy and surveillance space. London: Routledge.
Moore, D. (2011). The benevolent watch: therapeutic surveillance in drug treatment court. Theoretical Criminology, 15(3), 255-268. http://dx.doi.org/10.1177/1362480610396649

Nellis, M. (1991). The electronic monitoring of offenders in England and Wales: recent developments and future prospects. The British Journal of Criminology, 31(2), 165-185.

Nellis, M. (2009). Surveillance and confinement: explaining and understanding the experience of electronically monitored curfews. European Journal of Probation, 1(1), 41-65. http://dx.doi.org/10.1177/206622030900100104

Nolan, P. (2008). Capitalism and freedom. London: Anthem.

Padgett, K., Bales, W., \& Blomberg, T. (2006). Under surveillance: an empirical test of the effectiveness and consequences of electronic monitoring. Criminology \& Public Policy, 5(1), $61-$ 91. http://dx.doi.org/10.1111/j.1745-9133.2006.00102.x

Paterson, C. (2007). Street-level surveillance: human agency and the electronic monitoring of offenders. Surveillance \& Society, 4(2-3), 314-328.

Paterson, C. (2008). Commercial crime control and the electronic monitoring of offenders. Social Justice: a Journal of Crime, Conflict and World Order, 34(3-4), 98-110.

Paterson, C. (2012). Commercial crime control and the development of electronically monitored punishment: a global perspective. In M. Nellis, K. Beyens, \& D. Kaminski (Eds.), Electronically monitored punishment: critical perspectives. London: Routledge.

Paterson, C. (2014). Electronic monitoring and the global trade in (techno) corrections. Criminal Justice Matters, 95(1), 20-21. http://dx.doi.org/10.1080/09627251.2014.902202

Renzema, M. (1992). Home confinement programs: development, implementation and impact. In J. Byrne, A. Lurigio, \& J. Petersilia (Eds.), Smart sentencing: the emergence of intermediate sanctions. New York: Sage.

Römkens, R. (2006). Protecting prosecution: exploring the powers of law in an intervention program for domestic violence. Violence Against Women, 12(2), 160-186. http:// dx.doi.org/10.1177/1077801205284922. PMid:16382030

Rosell, N. (2011). Domestic violence, offenders and victims. In Confederation of European Probation Conference. Portugal.

Sibilla, G. (2012). Proyecto Buenos Aires Ciudad Segura. Cuadernos de Seguridad, 15, 203-228.

Sklansky, D. (2011). The Persistent Pull of Police Professionalism. Harvard: Harvard Kennedy School Executive Session on 
Policing and Public Safety. UC Berkeley Public Law Research Paper. Retrieved in 23 July 2014, from http://papers.ssrn. com/sol3/papers.cfm?abstract_id=1788463

Snelgrove, B. (2010). Electronic Monitoring in England \& Wales 1999-2010. Buenos Aires: UK Ministry of Justice Presentation.

Solano, V. (2012). Boton Antipanico: ya se Reciben Three Denuncias Diarias. Retrieved in 23 July 2014, from http:// www.clarin.com/sociedad/violencia_de_genero-boton_ antipanico-policia_metropolitana-sos-seguridad-alertavictoria_solano_0_712728868.html

Stenson, K. (2005). Sovereignty, biopolitics and the local government of crime in Britain. Theoretical Criminology, 9(3), 265-287.http://dx.doi.org/10.1177/1362480605054811

Taylor, C. (2012). Policing just outcomes. Perth: Edith Cowan University.
United Nations Office on Drugs and Crime - UNODC. (2013). The use of electronic monitoring bracelets as an alternative measure to imprisonment in Panama. United Nations Regional Office for Central America and Carribean. Retrieved in 19 July 2014, from http://www.unodc.org/ documents/ropan/TechnicalConsultativeOpinions2013/ Opinion_2/Advisory_Opinion_002-2013_ENGLISH_FINAL.pdf

Walklate, S. (2011). Reframing criminal victimization: finding a place for vulnerability and resilience. Theoretical Criminology, 15(2), 179-194. http://dx.doi. org/10.1177/1362480610383452

Webster, W. (2009). CCTV policy in the UK: reconsidering the evidence-based. Surveillance \& Society, 6(1), 10-22.

Whitfield, D. (1997). Tackling the tag. Winchester: Waterside Press.

Young, J. (2007). The vertigo of late modernity. London: Sage. 